\title{
A HŐGRADIENSEK HATÁSA AZ ÉPÍTŐANYAGOKBÓL EREDŐ RADON KIÁRAMLÁSI SEBESSÉGÉRE
}

\section{THE EFFECT OF TEMPERATURE GRADIENTS ON THE EXHALATION RATE OF RADON GENERATED BY BUILDING MATERIALS}

\author{
Botoș Marius-Lucian, ${ }^{1}$ Kisfaludi-Bak Zsombor ${ }^{2}$ \\ ${ }^{1}$ Kolozsvári Müszaki Egyetem, Építőmérnöki Kar; Babeş-Bolyai Tudományegyetem, Környezettudományi \\ és Környezetmérnöki Kar, Constantin Cosma Radon Laboratórium, Kolozsvár, Románia, marius.botos@ \\ mecon.utcluj.ro \\ ${ }^{2}$ Kolozsvári Müszaki Egyetem, Építőmérnöki Kar, Kolozsvár, Románia, zsombor.kisfaludi@mecon.utcluj.ro
}

\begin{abstract}
There is increasing interest in indoor air quality studies. The effect of exhaled radon from soil, walls and ceilings has well-known consequences on human health, so the importance of modelling has been established. The present paper examines radon exhalation, on the one hand, only in the case of diffusion and, on the other hand, diffusion and advection. Comparing the results of the two test types, we can determine how significant the effect of temperature gradients on radon exhalation is. For a broader investigation, we performed the parametric tests on several types of material, wall thickness and radon concentration.
\end{abstract}

Keywords: radon, exhalation, air quality, $C F D$.

\section{Összefoglalás}

A beltéri levegőminőségi vizsgálatok iránt növekvő érdeklődés mutatkozik. A talajból, épületfalakból és mennyezetekből kilégzett radon jól ismert következményekkel jár az emberi egészségre nézve, így adott a jelenség vizsgálatának fontossága. A jelen tanulmány a radonkibocsátást vizsgálja egyrészt csak diffúzió, másrészt diffúzió és advekció esetén. A két vizsgálattípus eredményeit összevetve megállapítható, hogy mennyire jelentős a hőmérséklet-gradiens hatása a radon kilégzésére. A szélesebb körü vizsgálathoz többféle anyag-, falvastagság-, illetve radonkoncentráció-paraméteres vizsgálatot végeztünk.

Kulcsszavak: radon, kibocsátás, levegö minőség, $C F D$.

\section{Bevezetés}

Hosszú távú radonsugárzásnak kitettség esetén fokozott a tüdőrák kialakulásának kockázata. A radonkilégzés forrásainak megtalálása széles körben érdeklődés tárgya. A radon elsősorban az alagsorok repedésein, kisebb réseken lép be a lakótérbe, viszont az új, légzáró lakások esetében az építőanyagokból kilégzett radon is növelheti a beltéri radonszintet [1]. Ez a tanulmány egy olyan multidiszciplináris projekt kis részét képezi, melynek célja a beltéri levegőminőség vizsgálata a radonszállítás modellezésének segítségével. Ez a szállítás kétféleképpen (és együttesen is) érhető el: diffúzió és advekció révén - a radonkoncentráció vagy a nyomás mértékétől függően (1. ábra).

$\mathrm{Az}$ energiahatékony lakásoknak szabályozott szellőztetésre van szükségük a felhalmozott vagy előállított energia elvesztésének minimalizálása érdekében. Az alacsony mértékű légcserélés a kültéri levegővel csökkentheti a levegő minőségét. 
Az alagsor légtisztítása alacsony radonkoncentrációhoz, az építőanyagokból származó radonkilégzés pedig váratlan eredményekhez vezethet. A légcsere továbbra is fontos szempont marad, irányítása javíthatja a levegő minőségét és csökkentheti a radonkoncentrációt. Az építőanyagokból és szerkezeti elemekből kilélegzett radon esetén a nyomás mértéke függ a hőmérséklet-különbségtől és a külső falakon észlelhető szél jelenlététől is. A nyomásgradienst és a fal permeabilitási tényezőjét figyelembe véve már nem elhanyagolható a sebesség jelenléte, így az (1) egyenlet is gazdagodik az advekciós kifejezéssel:

$$
\frac{D_{e}}{\varepsilon} \frac{\partial^{2} C}{\partial z^{2}}-\frac{1}{\varepsilon} \frac{\partial(v C)}{\partial z}-\lambda C+\phi=0
$$

A porózus elem belsejében lévő Darcy-sebesség állandó marad összenyomhatatlan levegőt feltételezve, a pórusok nem deformálódnak, és a radon-levegő keverék sűrűsége állandó (2):

$$
\frac{D_{e}}{\varepsilon} \frac{\partial^{2} C}{\partial z^{2}}-\frac{v}{\varepsilon} \frac{\partial(C)}{\partial z}-\lambda C+\phi=0
$$

$$
\begin{aligned}
& C(z)=C_{1} e^{r_{1} z}+C_{2} e^{r_{2} z}+\frac{\phi}{\lambda}=C_{1} e^{\frac{\left(\frac{v}{\varepsilon}\right)+\sqrt{\left(\frac{v}{\varepsilon}\right)^{2}+4 \frac{\lambda D_{e}}{\varepsilon}}}{\frac{2 D_{e}}{\varepsilon}} z}+C_{2} e^{\frac{\left(\frac{v}{\varepsilon}\right)-\sqrt{\left(\frac{v}{\varepsilon}\right)^{2}+4 \frac{\lambda D_{e}}{\varepsilon}}}{\frac{2 D_{e}}{\varepsilon}} z}+\frac{\phi}{\lambda} \\
& \begin{cases}C(0)=C_{\text {ext }} & C_{\text {ext }}=C_{1} e^{0}+C_{2} e^{0}+\frac{\phi}{\lambda} \\
C(L)=C_{\text {int }} & C_{\text {int }}=C_{1} e^{r_{1} L}+C_{2} e^{r_{2} L}+\frac{\phi}{\lambda}\end{cases} \\
& \left\{\begin{array}{l}
C_{\text {ext }}=C_{1}+C_{2}+\frac{\phi}{\lambda} C_{1}=C_{\text {ext }}-C_{2}-\frac{\phi}{\lambda} \\
C_{\text {int }}=\left(C_{\text {ext }}-C_{2}-\frac{\phi}{\lambda}\right) e^{r_{1} L}+C_{2} e^{r_{2} L}+\frac{\phi}{\lambda}
\end{array}\right. \\
& C_{2}=\frac{C_{\text {int }}-\left(C_{e x t}-\frac{\phi}{\lambda}\right) e^{r_{1} L}-\frac{\phi}{\lambda}}{e^{r_{2} L}-e^{r_{1} L}} \\
& C_{1}=C_{e x t}-\frac{C_{i n t}-\left(C_{e x t}-\frac{\phi}{\lambda}\right) e^{r_{1} L}-\frac{\phi}{\lambda}}{e^{r_{2} L}-e^{r_{1} L}}-\frac{\phi}{\lambda} \\
& C(z)=\left(C_{e x t}-\frac{C_{i n t}-\left(C_{e x t}-\frac{\phi}{\lambda}\right) e^{r_{1} L}-\frac{\phi}{\lambda}}{e^{r_{2} L}-e^{r_{1} L}}-\frac{\phi}{\lambda}\right) e^{r_{1} z}+\left(\frac{C_{\text {int }}-\left(C_{\text {ext }}-\frac{\phi}{\lambda}\right) e^{r_{1} L}-\frac{\phi}{\lambda}}{e^{r_{2} L}-e^{r_{1} L}}\right) e^{r_{2} z}+\frac{\phi}{\lambda}
\end{aligned}
$$




\section{Parametrikus vizsgálat}

Annak érdekében, hogy a tégla-, illetve betonfalakon és födémeken keresztüli kilégzési sebességre gyakorolt advekció (konvekció) diffúzión túli hatását kimutathassuk, parametrikus vizsgálatot végeztünk $A$ használt építőanyagok: tégla és beton. A betonelemekből származó radonkilégzési sebességet a betonelem korától, porozitásától, a levegő páratartalmától, a beton típusától és a levegő hőmérsékletétől tettük függővé [2].

Ha az elemeket perimetrálisnak tekintettük, akkor a külső koncentrációt 0-nak vettük, az elemek beltéri felületén a radonkoncentráció: 50, 100, 300,500 és $1000 \mathrm{~Bq} / \mathrm{m}^{3}$ volt.

Az elemeket 10, 15, 20, 25 és $30 \mathrm{~cm}$ vastagnak tekintettük. A két anyag radonképződésének sebességét a szakirodalomban [3] található átlagértékeknek feleltettük meg (radonkoncentráció, sürűség, kibocsátási tényező és porozitás). Így tégla esetén $\varphi=0,083 \mathrm{~Bq} / \mathrm{m}^{3} \mathrm{~s}$ és beton esetén $\varphi=0,26$ $\mathrm{Bq} / \mathrm{m}^{3} \mathrm{~s}$. A diffúziós együttható kilégzési arányok kialakulására gyakorolt hatásának kimutatása érdekében a következő minimális és maximális tartományokkal számoltunk (téglára 8,4e-8 és 3,4e-7 $\mathrm{m}^{2} / \mathrm{s}$; betonra $2,1 \mathrm{e}-8$ és $5,2 \mathrm{e}-7 \mathrm{~m}^{2} / \mathrm{s}$ ).

A 10 és a $25 \mathrm{~cm}$-es tégla- és betonfal kilégzési sebessége a 2. és a 3. ábrákon látható.

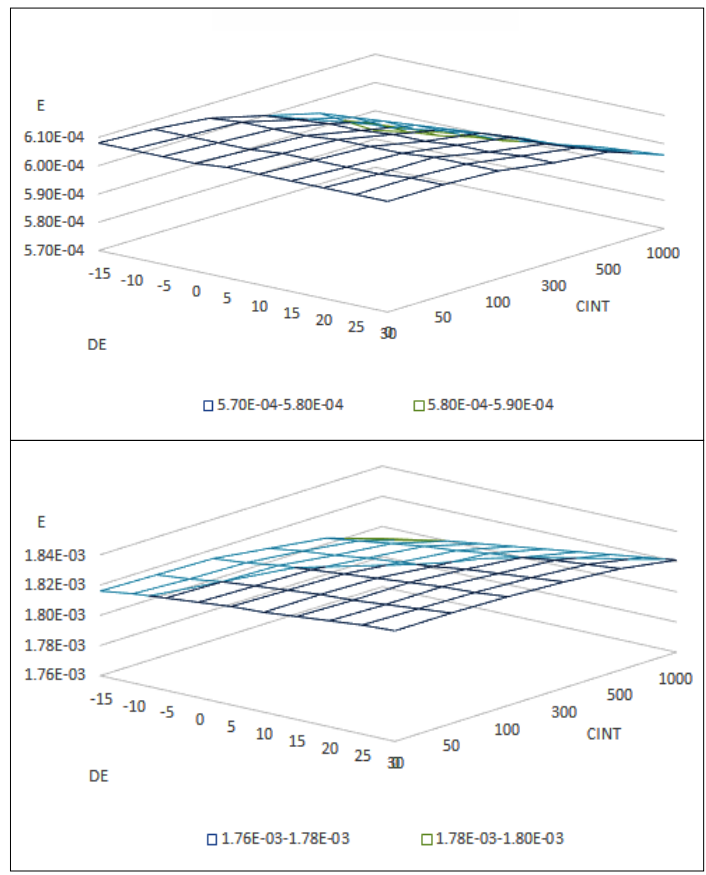

2. ábra. Radonkilégzési sebesség $10 \mathrm{~cm}$-es tégla (első) és beton (második) falakra, diffúzió és advekció esetén
A $10 \mathrm{~cm}$-es tégla- és betonfal kilégzési sebessége csak a diffúzió hatását véve figyelembe a 4. ábrán van bemutatva.

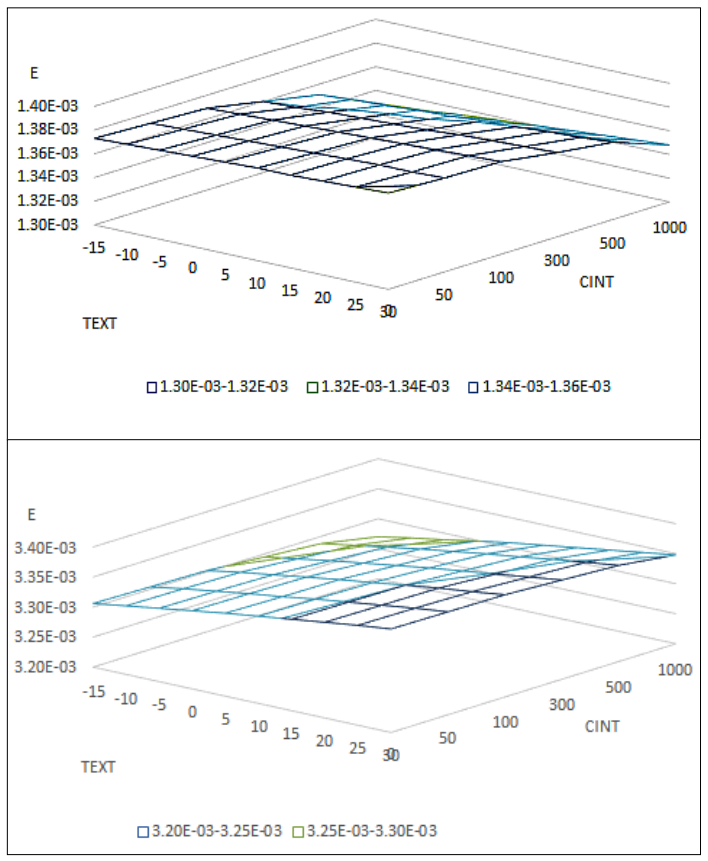

3. ábra. Radonkilégzési sebesség $25 \mathrm{~cm}$-es tégla (első) és beton (második) falakra, diffúzió és advekció esetén
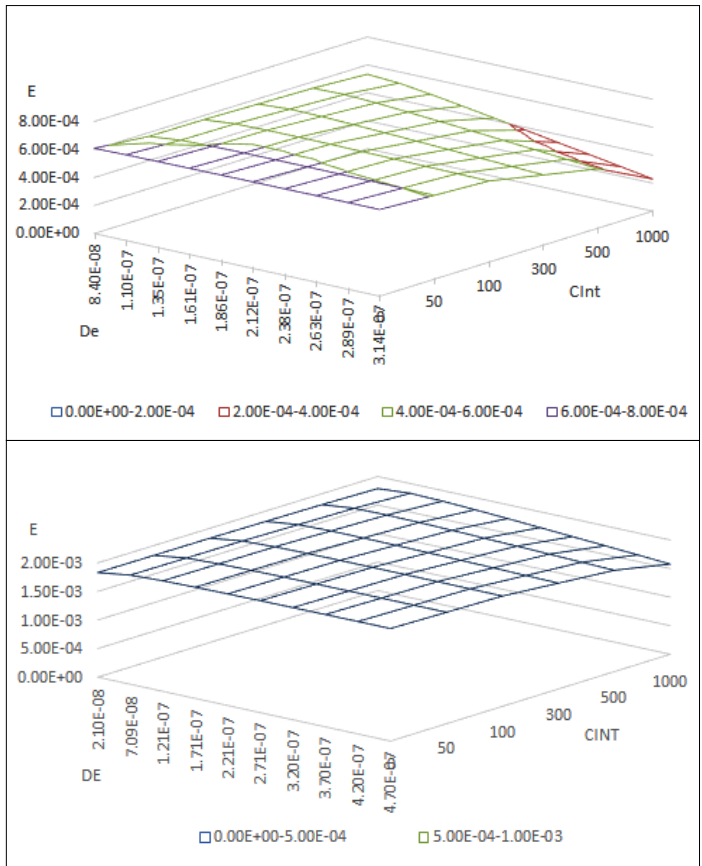

4. ábra. Csak diffúzióból származó radonkilégzés mértéke $10 \mathrm{~cm}$-es tégla (első) és beton (második) falak esetén 
A $25 \mathrm{~cm}$-es tégla- és betonfal kilégzési sebessége csak a diffúzió hatását véve figyelembe az 5. ábrán tekinthető meg.

Az eredményeket az ANSYS felületen keresztül kaptuk és számos UDF-et írtunk az eredmények iteratív generálására CSV formátumban.

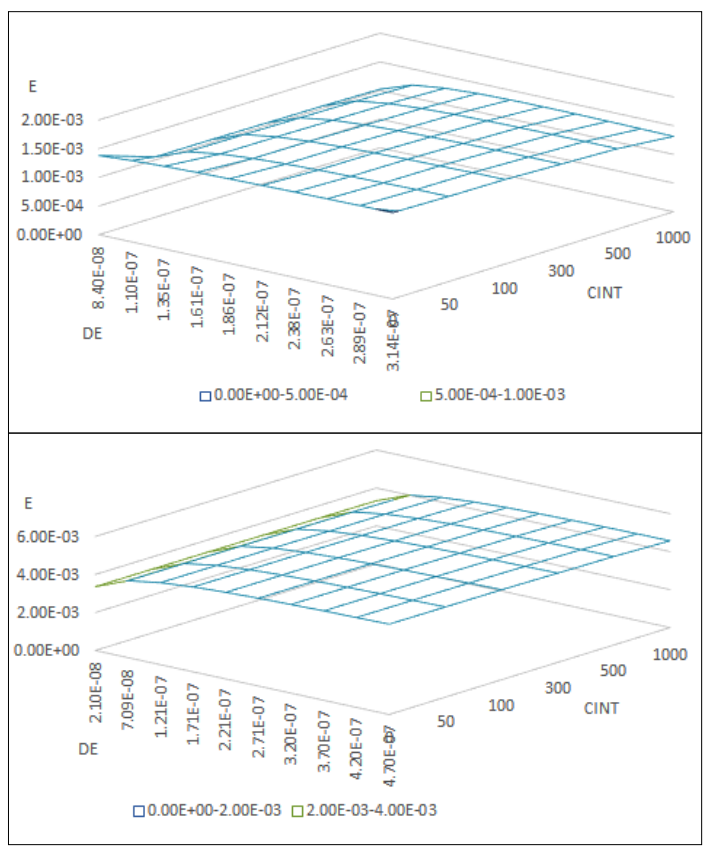

5. ábra. Csak diffúzióból származó radonkilégzés mértéke $25 \mathrm{~cm}$-es tégla (első) és beton (második) falak esetén

\section{Következtetések}

A hőmérséklet-gradiensekkel rögzített különbségek jelentéktelenek, a külső hőmérsékletek által generált nyomáskülönbségek túl kicsik, és az elemek permeabilitása túl alacsony a szállítási egyenlet advekciós kifejezésében ahhoz, hogy az meghatározó lehessen a kilégzési sebesség számításában.

\section{Köszönetnyilvánítás}

Jelen munka az ID P_37_229. számú, 22/01.09.2016 szerződésszámú, „Smart Systems for Public Safety through Control and Mitigation of Residential Radon linked with Energy Efficiency Optimization of Buildings in Romanian Major Urban Agglomerations SMART-RADEN”- POC Programme című projekt keretében részesült támogatásban.

Jelen munkát szintén támogatta Magyarország Collegium Talentum 2018 programja.

\section{Szakirodalmi hivatkozások}

[1] Chen J., Rahman N. M., Abu Atiya I.: Radon exhalation from building materials for decorative use. Journal of Environmental Radioactivity 101/4. (2010) 17-22.

https://doi.org/10.1016/j.jenvrad.2010.01.005

[2] Apostu A.: Radon transport through building materials. PhD-dolgozat, Babeș-Bolyai Tudományegyetem, Kolozsvár, Románia, 2011.

[3] Font Guiteras L.: Radon generation, entry and accumulation indoors. PhD Thesis, Universitat Autònoma de Barcelona, Spain, 1997. 